\title{
A Comparative Study Regarding the Efficiency of Two Different Systems of Chlorhexidine Release in Periodontal Therapy
}

\author{
IONUT LUCHIAN ${ }^{1}$, IOANA MARTU ${ }^{1 *}$, MIHAELA MOSCALU ${ }^{2 *}$, GIORGIO NICHITEAN ${ }^{1}$, \\ SORINA-MIHAELA SOLOMON ${ }^{1}$, MARIA-ALEXANDRA MARTU ${ }^{1}$, \\ GEORGETA LAZA-DEMIRBUKEN ${ }^{3}$, ANCUTA GORIUC ${ }^{1}$ \\ ${ }^{1}$ Grigore T. Popa University of Medicine and Pharmacy, Faculty of Dental Medicine, 16 Universitatii Str., 700115, Iasi, \\ Romania \\ ${ }^{2}$ Grigore T. Popa University of Medicine and Pharmacy, Faculty of Medicine, 16 Universitatii Str., 700115, Iasi, Romania \\ ${ }^{3}$ Grigore T. Popa University of Medicine and Pharmacy, Department of Periodontology, 16 Universitatii Str., 700115, Iasi, \\ Romania
}

\begin{abstract}
Supragingival scaling and especially the subgingival one represent together with root planning (SRP) the main elements of periodontal therapy. Chlorohexidine gluconate represents an realiable option as an anstiseptic that can be associated with SRP in order to reduce the probing depth $(P D)$. The current research involved selecting 30 pacients with periodontal disease and at least one situs with $P D$ greater than $5 \mathrm{~mm}$. The patients were randomly and equally divided into three groups that were named $A, B$ and $C$. The patients that were included in Group A received SRP without any additional substances. At the level of Group B the patients received SRP and inside the pockets with PD greater than $5 \mathrm{~mm}$ we applied the topical gel Glucosite Gel (Cerkamed) for three consecutive times, every 24 hours. Patients that were included in Group C were treated using SRP and at the level of pockets with $P D$ greater or equal with $5 \mathrm{~mm}$ we applied the product PerioChip (Dexcel). Our results proved that for all three groups the values of PD recorderd after treatment were significantly lower compared to the initial ones $(p>0.05)$ but in case of group $C(S R P+$ PerioChip) the the drop of the PD values were significantly higher. After treatment the values of PBI were significantly lower in the case of patients included in group $C$ (SRP+PerioChip) in comparison with the ones recorded in patients included in group A (SRP) $(p=0.00053)$ or group (SRP+Glucosite) $(p=0.0178)$. The slow release of chlorohexidine gluconate into periodontal pockets is an effective solution, superior to the topical application of this active product.
\end{abstract}

Keywords: PerioChip, Chlorohexidine, Probing depth, PBI.

\section{Introduction}

Supragingival scaling and especially the subgingival one represent together with root planning (SRP) the main elements of periodontal therapy [1-5].

Lately, other studies emphasized the necessity of optimizing these therapeutic procedures through using some additional products that can increase the efficiency of SRP [6-8].

Chlorohexidine gluconate represents an realiable option as an anstiseptic that can be associated with SRP in order to reduce the probing depth (PD) [9-11].

*email:ioanamartu@gmail.com; mmoscalu@yahoo.com All authors had equal contribution to this article with the one of the first author. 


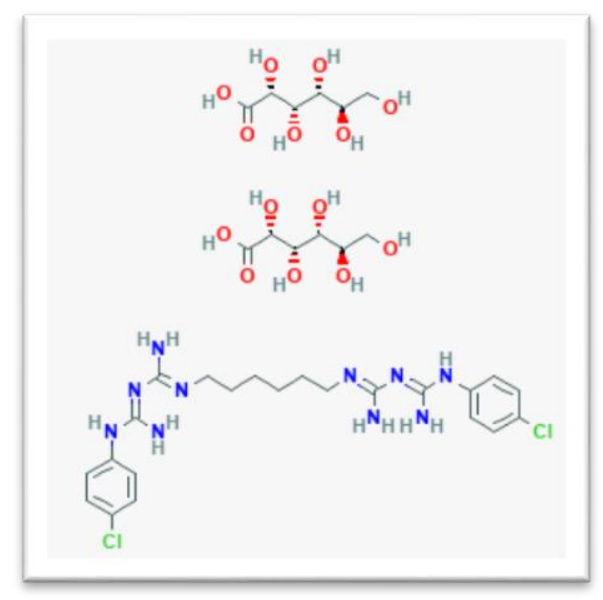

Figure 1.Chemical structure FiglicerXPgiQmonate electronic probe

\section{Materials and methods}

The current research involved selecting 30 pacients with periodontal disease and at least one situs with PD greater than $5 \mathrm{~mm}$.

The patients were randomly and equally divided into three groups that were named A, B and C.

The patients included in Group A received SRP without any additional substances. At the level of Group B the patients received SRP and inside the pockets with PD greater than $5 \mathrm{~mm}$ we applied the topical gel Glucosite Gel (Cerkamed) for three consecutive times, every 24 hours.

Patients included in Group C were treated using SRP and at the level of pockets with PD greater or equal with $5 \mathrm{~mm}$ we applied the product PerioChip (Dexcel) (Figure 2).

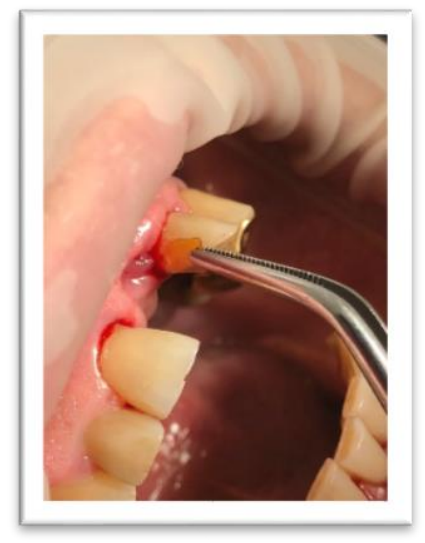

Figure. 2. The insertion of PerioChip

The measuring of probing depth was performed using an electronic probe Pa-On (Orange Dental) for minimizing the potential reading errors and in the same time to eliminate the potential subjectivism of the investigators regarding the anticipation of the results of the current study (Figure 3).

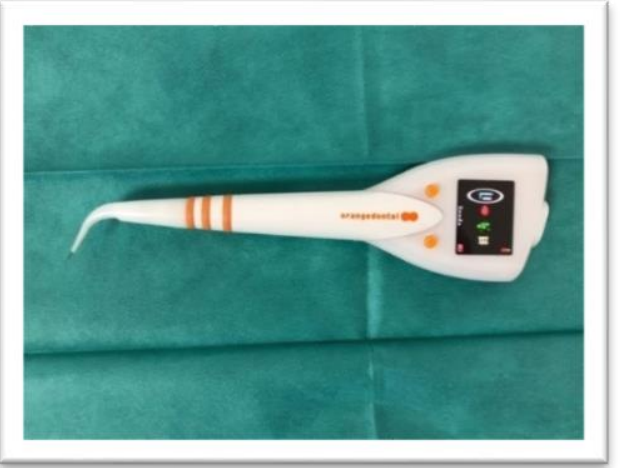

Figure 3. PaOn electronic probe 
When recording the probing depth in periodontal pockets, we also determined the papillary bleeding index (PBI), in order to correlate this issue with the level of inflammation that could be clinically identified. The evaluation of the papillary bleeding index (PBI) was made after using a conventional, Williams type periodontal probe, so that the result would not be influenced by the use of a nonconventional electronic probe.

\section{Results and discussions}

The results of this study can be synthesized in the following tables (Table 1,2).

Table 1. Probing depth before and after treatment

\begin{tabular}{ccccccc}
\hline \multirow{2}{*}{$\begin{array}{c}\text { Nr. } \\
\text { crt. }\end{array}$} & \multicolumn{2}{c}{ Group A (SRP) } & \multicolumn{2}{c}{ Group B (SRP+Glucosite) } & \multicolumn{2}{c}{ Group C (SRP+PerioChip) } \\
\hline 1. & $7.5 \mathrm{~mm}$ & $5.5 \mathrm{~mm}$ & $7.00 \mathrm{~mm}$ & $4.5 \mathrm{~mm}$ & $7.00 \mathrm{~mm}$ & $3.5 \mathrm{~mm}$ \\
\hline 2. & $6.00 \mathrm{~mm}$ & $4.5 \mathrm{~mm}$ & $6.5 \mathrm{~mm}$ & $4.00 \mathrm{~mm}$ & $6.00 \mathrm{~mm}$ & $3.00 \mathrm{~mm}$ \\
\hline 3. & $5.5 \mathrm{~mm}$ & $4.5 \mathrm{~mm}$ & $5.00 \mathrm{~mm}$ & $3.5 \mathrm{~mm}$ & $5.5 \mathrm{~mm}$ & $2.5 \mathrm{~mm}$ \\
\hline 4. & $6.5 \mathrm{~mm}$ & $4.00 \mathrm{~mm}$ & $6.5 \mathrm{~mm}$ & $3.5 \mathrm{~mm}$ & $6.00 \mathrm{~mm}$ & $2.5 \mathrm{~mm}$ \\
\hline 5. & $5.00 \mathrm{~mm}$ & $3.5 \mathrm{~mm}$ & $5.5 \mathrm{~mm}$ & $4.5 \mathrm{~mm}$ & $5.00 \mathrm{~mm}$ & $2.5 \mathrm{~mm}$ \\
\hline 6. & $6.00 \mathrm{~mm}$ & $4.5 \mathrm{~mm}$ & $6.5 \mathrm{~mm}$ & $5.00 \mathrm{~mm}$ & $6.00 \mathrm{~mm}$ & $3.0 \mathrm{~mm}$ \\
\hline 7. & $7.5 \mathrm{~mm}$ & $5.5 \mathrm{~mm}$ & $7.00 \mathrm{~mm}$ & $4.5 \mathrm{~mm}$ & $6.5 \mathrm{~mm}$ & $3.5 \mathrm{~mm}$ \\
\hline 8. & $6.00 \mathrm{~mm}$ & $4.5 \mathrm{~mm}$ & $6.5 \mathrm{~mm}$ & $5.00 \mathrm{~mm}$ & $6.00 \mathrm{~mm}$ & $2.5 \mathrm{~mm}$ \\
\hline 9. & $7.00 \mathrm{~mm}$ & $5.5 \mathrm{~mm}$ & $7.5 \mathrm{~mm}$ & $5.5 \mathrm{~mm}$ & $7.00 \mathrm{~mm}$ & $4.00 \mathrm{~mm}$ \\
\hline 10. & $6.5 \mathrm{~mm}$ & $5.00 \mathrm{~mm}$ & $6.00 \mathrm{~mm}$ & $4.00 \mathrm{~mm}$ & $5.5 \mathrm{~mm}$ & $3.00 \mathrm{~mm}$ \\
\hline
\end{tabular}

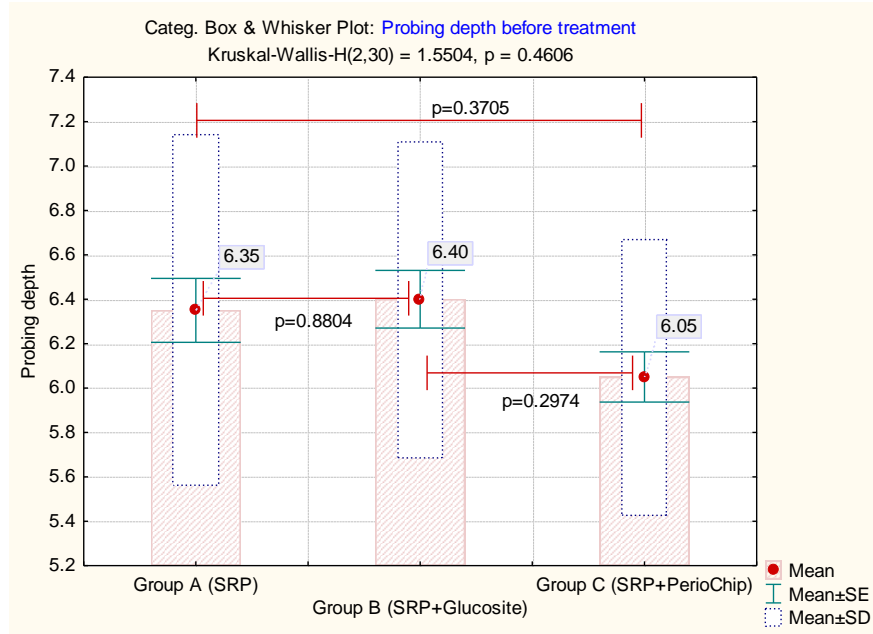

a)

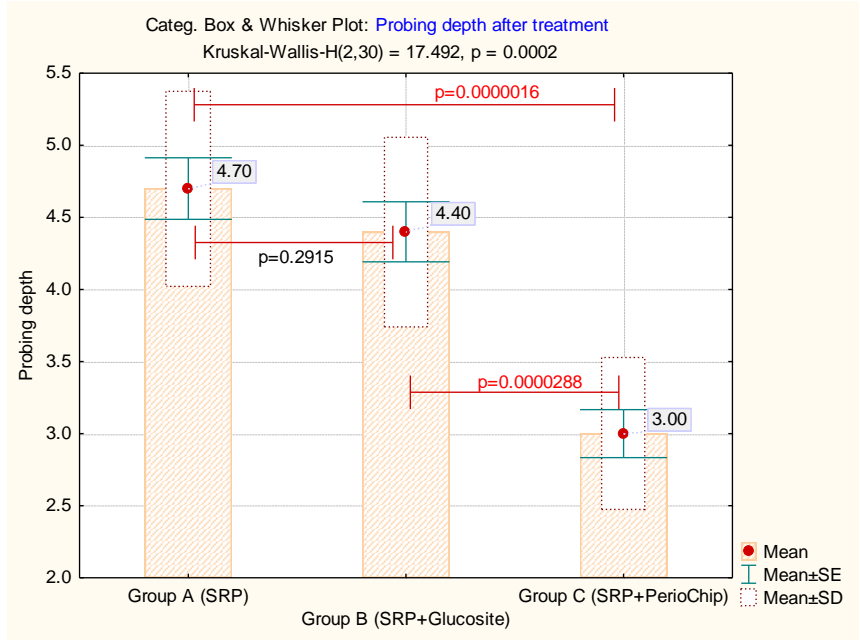

b) 


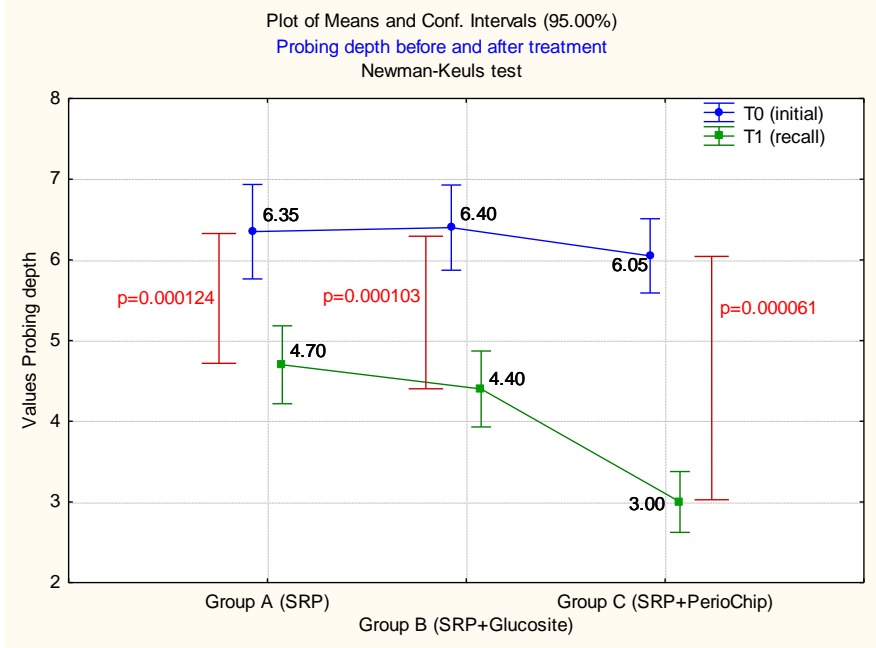

Figure 4 a-c. Evalution of differences between mean values for probing depth before and after treatment

The analysis of mean PD values recorded before treatment didn't show any significant statistical differences regardless the type of treatment (Figure 4A).

After treatment we can notice significant lower values in Group C (SRP+Periochip) when comparing them to both Group A (SRP) ( $\mathrm{p}<0.001)$ and Group B (SRP+Glucosite) $(\mathrm{p}=0.000028)$.

As well we noticed the fact that PD values recorded in cases included in Group A $(p=0.2915)$ don't show a stastistical difference compared to the patients included in Group B (Figure 4 B).

Our results proved that for all three groups the values of PD recorderd after treatment were significantly lower compared to the initial ones ( $p>0.05$ ) but in case of group C(SRP+PerioChip) the the drop of the PD values were significantly higher (Figure 4C).

Table 2. Papillary bleeding index (pbi) before and after treatment

\begin{tabular}{|c|c|c|c|c|c|c|}
\hline \multirow{2}{*}{$\begin{array}{l}\text { Nr. } \\
\text { crt. }\end{array}$} & \multicolumn{2}{|c|}{ Group A (SRP) } & \multicolumn{2}{|c|}{ Group B (SRP+Glucosite) } & \multicolumn{2}{|c|}{ Group C (SRP+PerioChip) } \\
\hline & T0 (initial) & T1 (recall) & T0 (initial) & T1 (recall) & T0 (initial) & T1 (recall) \\
\hline 1. & 4 & 3 & 3 & 2 & 3 & 1 \\
\hline 2. & 3 & 2 & 3 & 2 & 3 & 1 \\
\hline 3. & 3 & 2 & 3 & 2 & 3 & 1 \\
\hline 4. & 3 & 2 & 3 & 2 & 3 & 1 \\
\hline 5. & 2 & 1 & 3 & 2 & 3 & 2 \\
\hline 6. & 3 & 3 & 3 & 1 & 2 & 1 \\
\hline 7. & 4 & 2 & 4 & 2 & 3 & 1 \\
\hline 8. & 3 & 2 & 3 & 1 & 3 & 0 \\
\hline 9. & 3 & 2 & 3 & 1 & 3 & 0 \\
\hline 10. & 2 & 1 & 3 & 1 & 2 & 0 \\
\hline
\end{tabular}




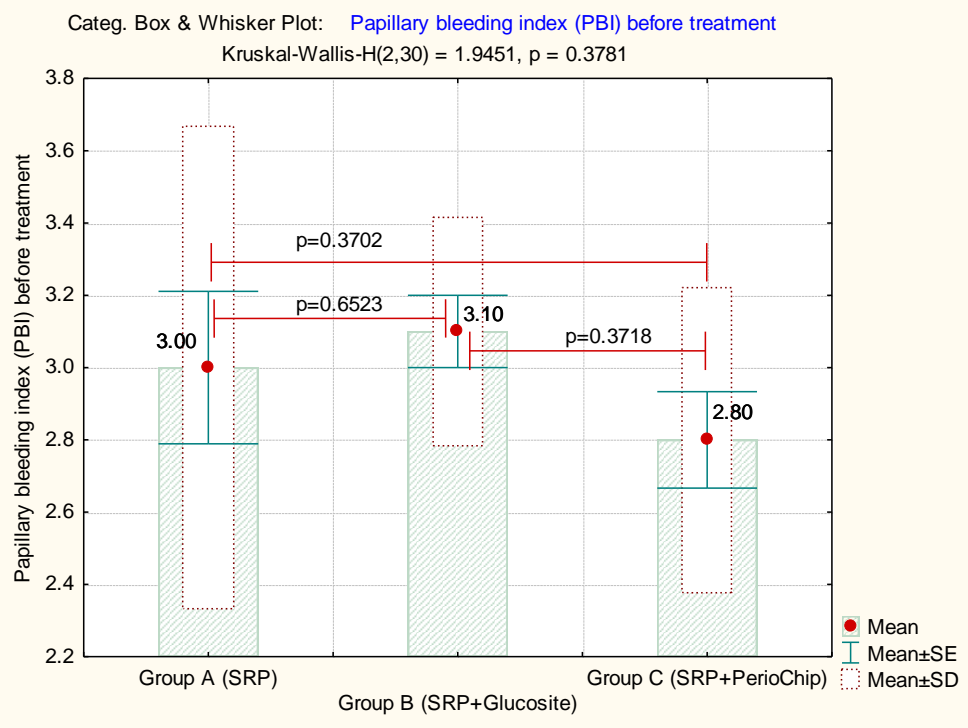

Categ. Box \& Whisker Plot: Papillary bleeding index (PBI) after treatment

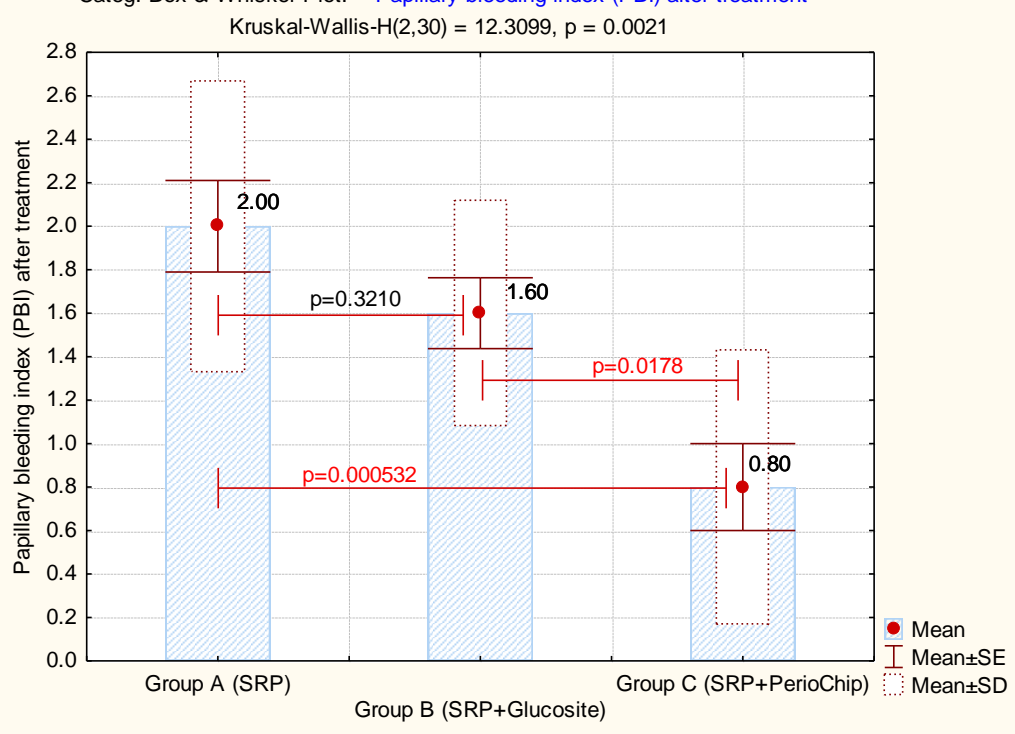

Plot of Means and Conf. Intervals (95.00\%)

Papillary bleeding index (PBI) before and after treatment

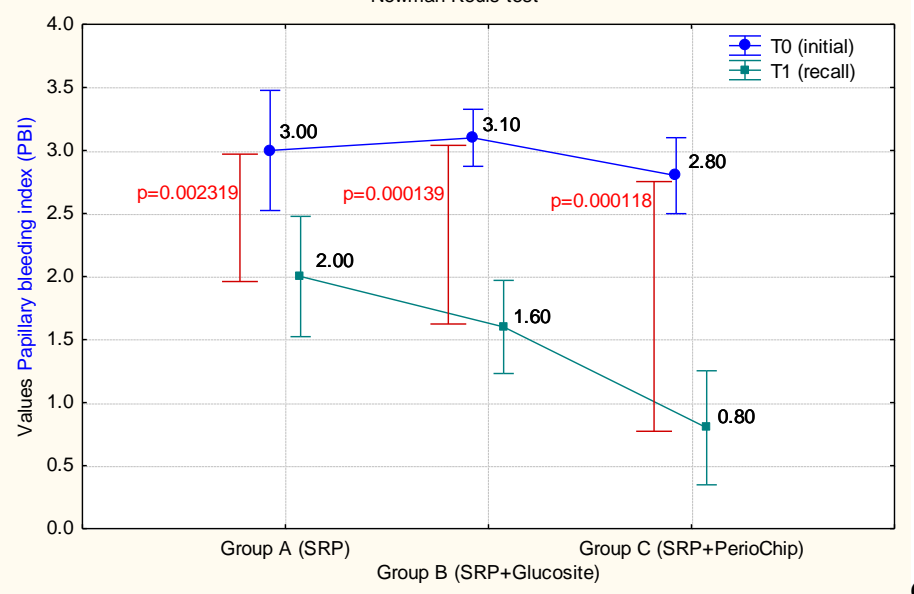

Figure 5 a-c. Evalution of differences between mean values papillary bleeding index $(\mathrm{PBI})$ before and after treatment 
The patients included in the three study groups didn't show statistical significant differences in the values of PBI ( $>>0.05)$ (Figure 5A).

After treatment the values of PBI were significantly lower in the case of patients included in group $\mathrm{C}$ (SRP+PerioChip) in comparison with the ones recorded in patients included in group A (SRP) $(\mathrm{p}=0.00053)$ or group (SRP+Glucosite) $(\mathrm{p}=0.0178)$.

In case of the patients included in group A (SRP) the values of PBI didn't show any significant differences compared to the ones included in group B (SRP+Glucosite) $(\mathrm{p}=0.321)$ (Figure $5 \mathrm{~B})$.

The comparative analysis of the values recorded befored treatment with the ones recorded after treatment showed a significant drop in all study groups.

Periodontal disease is an inflammatory condition with a major component related to the presence of bacterial plaque [12]. The pathogenic potential of the bacterial plaque affects the progression and severity of the periodontal disease and can lead in time to periodontal ligament destruction and bone damage[13,14].

Previous studies have shown that mechanical SRP treatment can be effective in removing microbial flora and its association with chlorhexidine local administration increases treatment efficiency [15-17].

In our study we compared the treatment efficiency using two different products: Glucosite and Perio Chip associated with SRP treatment for a short period of time. Glucosite is a gel containing $0.2 \%$ chlorhexidine digluconate and 3\% hydrogen peroxide, recommended for the preparation and cleaning of periodontal pockets [18].

PerioChip is a small biodegradable chip containing chlorhexidine gluconate, which is the goldstandard antimicrobial agent [13].

Initial studies on the oral use of chlorhexidine suggested that this dicationic bisbiguanide demonstrated a plaque inhibitory effect [20-21].

Van der Ouderaa has previously described the ideal antimicrobial properties to control periodontal disease and chlorhexidine possesses most of these characteristics [22]. Thus, a local system for chlorhexidine releasing together with conventional therapy could control the progression of periodontal disease more effectively[23]. Previous studies have shown that using Perio Chip maintains a concentration of chlorhexidine over $125 \mathrm{mg} / \mathrm{ml}$ for 7-10 days in the crevicular fluid, a concentration that causes the death of over $99 \%$ of the subgingival microorganisms from periodontal pockets[24].

The use of local delivery systems with antimicrobial agents should not replace the need for thorough SRP, which remains the most important and the primary treatment modality[25].

Perio Chip is a biodegradable chip used for reduction of pocket depth in patients with periodontitis and pockets depth more then or equal to $5 \mathrm{~mm}$, when used with scaling and root planing (SRP). Thus, the use of Periochip can not only decrease the bacterial load of the periodontal pockets but also their recolonization. This can be performed through reducing the virulence of certain periodontal pathogens by inhibiting their proteolytic and glycosidic activities as these activities aid in producing potential virulence factors[26-27].

In our study the results showed a decrease of both studied parameters: the depth of the periodontal pockets and the bleeding index, both when we used the Glucosite gel but also in case of the Perio Chip treatment. The most important differences we observed in group C - SRP and Periochip treated. These findings are in accordance with the results obtained in studies conducted by Stabholz et al.,[28] Soskolne et al.,[29] Jeffcoat et al.,[30] Heasman et al.,[31] Azmak et al.,[32] Mizrak et al.[33]

This result may be considered a validation of the treatment protocol SRP plus adjuvant treatment of Perio Chip type.

Although in both study groups B (SRP+Glucosite) and C (SRP+PerioChip) the results obtained were better that in study group A (SRP), it appears that the patients included in group $\mathrm{C}$ had better results than those in the other two groups. 


\section{Conclusions}

Chlorohexidine gluconate is a genuine and viable adjuvant treatment for mechanical treatment.

The slow release of chlorhexidine gluconate into periodontal pockets is an effective solution, superior to the topical application of this active product.

This method has a significant clinical relevance in reducing probing depth and in controlling inflammation.

\section{References}

CHACKARTCHI, T., HAMZANI, Y., SHAPIRA, L., POLAK, D., Oral Health Prev Dent. 2019, 17, no. 2 , p.167-171.

JEFFCOAT, M.K., BRAY, K.S., CIANCIO, .SG., DENTINO, A.R., FINE, D.H., GORDON, J.M., GUNSOLLEY, J.C., KILLOY, W.J., LOWENGUTH, R.A., MAGNUSSON, N.I., OFFENBACHER, S., PALCANIS, K.G., PROSKIN, H.M., FINKELMAN, R.D., FLASHNER, M., J Periodontol., 1998, 69, no.9, pp.989-997.

SOLOMON, S.M., STOLERIU, S., FORNA AGOP, D., ET AL., Mater.Plast., 53, (2), 2016, 304 PASARIN, L., URSARESCU-SUFARU, I., MARTU, I., SOLOMON, S., MARTU-STEFANACHE, A., CIOCAN-PENDEFUNDA, A., MARTU, S., Rom J of Oral Rehab, 2016, 8, no.4, pp.90-96. SOLOMON, S.M., TIMPU, D., FORNA-AGOP, D., et al., Mater.Plast., 53, (3), 2016, 546

6. ROXANNE, A.L., GREENSTEIN, G., Periodontol 2000, 1995, 9,p.14-22.

7. NICOLAE, V., CHISCOP, I., CIORANU IBRIC, V.S., MARTU, M.A., LUCHIAN, A.I., MARTU, S., SOLOMON, S.M., Rev Chim , 66, (12), 2015, 2121

8. MARTU, M.A., SAVIN, C., KHARITOS, K., et al,. Rom J of Oral Rehab, 2017, 9, no.2, pp.21-25

9.PATTNAIK, S., ANAND, N., CHANDRASEKARAN, S.C., CHANDRASHEKAR, L.,

MAHALAKSHMI, K., SATPATHY, A., Eur J Clin Microbiol Infect Dis., 2015, 34, no.10, pp.

2103-2110

10. LECIC, J., CAKIC, S., JANJIC PAVLOVIC, O., Acta Odontol Scand., 2016, 74, pp.502-507.

11. BOGDAN, M., TICA, I., GHEORGHE, D.N., SILOSI, I., SOLOMON, S., MARTU, I., SURLIN, P., CHISCOP, I., BUDACU, C., Rev. Chim., 67, (12), 2016, 2651

12. MARTU, I., GORIUC, A., MARTU, M.A., VATA, I., BACIU, R., MOCANU, R., SURDU, A.E., POPA, C., LUCHIAN, I., Rev. Chim., 68, (10), 2017, 2407

13. LUCHIAN, I. , MARTU, I., MARTU, C. , GORIUC, A., BELDIMAN, A., MARTU, S., Rev. Chim., 67, (6), 2016, 1073

14. BACKLUND, C.J., SERGESKETTER, A.R., OFFENBACHER, S., SCHOENFISCH, M.H., J Dent Res., 2014, 93, no.11, pp.1089-1094

15. PERINETTI, G., PAOLANTONIO, M., CORDELLA, C., D’ERCOLE, S., SERRA, E., PICCOLOMINI, R., J Clin Periodontol., 2004, 31, pp. 273-281

16. TABARY, N., CHAI, F., BLANCHEMAIN, N., NEUT, C., PAUCHET, L., BERTINI, S., DELCOURT-DEBRUYNE, E., HILDEBRAND, H.F., MARTEL, B., Acta Biomater., 2014, 10, no,1, pp. 318-329.

17. PAOLANTONIO, M., D'ANGElO, M., GRASSI, R.F., PERINETTI, G., PICCOLOMINI, R., PIZZO, G., ANNUNZIATA, M., D'ARCHIVIO, D., D'ERCOLE, S., NARDI, G., GUIDA, L., J Periodontol., 2008, 79 no. 2, pp. 271-282.

18. CHEN, C., SLOTS, J., Curr Opin Periodontol., 1993, 12, pp. 71-77.

19. HEASMAN,P.A., HEASMAN, L., STACEY, F., MCCRACKEN, G.J., J Clin Peridontol., 2001, 28, pp. 90-95.

20. MIZRAK, T., GÜNCÜ, G.N., CAGLAYAN, F., BALCI, T.A., AKTAR, G.S., IPEK, F., J Periodontol., 2006,77, no.3, pp. 437-443.

21. SOSKOLNE, W.A., HEASMAN, P.A., STABHOLZ, A., SMART, G.J., PALMER, M., FLASNER. M., J Periodontol., 1997, 68, pp.32-38

22.VAN DER OUDERAA, F.J., J Clin Periodontol., 1991, 18, pp. 447-454. 
23. HENKE, C.J., VILLA, K.F., AICHELMANN-REIDY, M.E., ARMITAGE, G.C., EBER, R.M., GENCO, R.J., KILLOY, W.J., MILLER, D.P., PAGE, R.C., POLSON, A.M., RYDER, M.I., SILVA, S.J., SOMERMAN, M.J., VAN DYKE, T.E., WOLFF, L.F., EVANS, C.J., FINKELMAN, R.D., J Am Dent Assoc., 2001, 132, no. 11), pp. 557-569

24. JEFFOCOAT MK, BRAY KS, CIANCIO SG, DENTINO AR, FINE DH, GORDON JM, J Periodontol., 1998, 69, pp. 989-997

25. CERVONE, F., TRONSTA,D. L., HAMMOND, B., Endod Dent Traumatol., 1990, 6, no.1), pp. $33-$ 36.

26. HANE, P.J., PURVIS, J.P., Ann Periodontol., 2003, 8, pp.79-98

27. GOMES RODRIGUES, I.F., MACHION, L., CASATI, M.Z., NOCITI, F.H., TOLEDO, S., SALLUM, A.W., J Periodontol., 2007, 78, pp. 624-628.

28. STABHOLZ, A., SELA, M.N., FRIEDMAN, M., GOLUMB, G., SOSKOLNE, A., J Clin Periodontol, 1986, 13, pp. 783-788.

29. SOSKOLNE, W.A., HEASMAN, P.A., STABHOlZ, A., SMART, G.J., PALMER, M., FLASHNER, M., J Periodontol, 1997, 68, pp.32-38.

30. JEFFCOAT, M.K., BRAY, K.S., CIANCIO, S.G., DENTINO, A.R., FINE, D., GORDON, J.M., J Periodontol, 1998, 69, pp. 989-997.

31.HEASMAN, P.A., HEASMAN, L., STACEY, F., MC CRACKEN, G.I., J Clin Periodontol, 2001, 28, pp. 90-95.

32.AZMAK, N., ATILLA, G., LUOTO, H., SORSA, T., J Periodontol, 2002, 73, pp. 608-615.

33.MIZRAK, T., GUNCU, G.N., CAGLAYAN, F., BALCI, T.A., AKTAR, G.S. IPEK, F., J Periodontol, 2006, 77, pp. 4374-4380.

Manuscript received: 27.02 .2020 